\title{
Substance use among high school students in Erbil City, Iraq: prevalence and potential contributing factors
}

Nazar Mahmood, ${ }^{1}$ Samir Othman, ${ }^{1}$ Namir Al-Tawil ${ }^{1}$ and Tariq Al-Hadithi ${ }^{1}$

${ }^{1}$ Department of Community Medicine, College of Medicine, Hawler Medical University-Erbil, Kurdistan Region, Iraq (Correspondence to: Nazar A. Mahmood: nazaraljaf@yahoo.com).

\begin{abstract}
Background: Substance use among adolescents, especially smoking and alcohol consumption, has become a public health concern in the Kurdistan Region, Iraq, in the past 10 years.

Aims: This study aimed to determine the prevalence of substance use and certain associated factors among high school students in Erbil City, Kurdistan Region, Iraq.

Methods: A cross-sectional study was conducted using a multistage cluster sampling technique to collect a sample of 3000 students. A modified version of the School Survey on Drug Use from the United Nations Office on Drugs and Crime was used for data collection. Binary logistic regression models were used to identify risk factors for substance use.

Results: The lifetime prevalence rates of cigarettes smoking, waterpipe smoking and alcohol consumption were $27.6 \%$, $23.6 \%$ and $3.7 \%$, respectively. Male gender, age 17-19 years, smoker in the family, and easy accessibility of cigarettes were significantly associated with cigarette smoking. Factors significantly associated with waterpipe smoking were male gender, age 17-19 years, waterpipe smoker in the family, waterpipe smoker friend, and easy accessibility. Male gender, alcohol dependent in the family, alcohol-dependent friend, easy accessibility of alcohol, and low family income were significant predictors of alcohol consumption.

Conclusions: The prevalence of cigarette smoking and waterpipe use was high in the studied sample. Possible explanations for this finding might be the use of flavoured tobacco associated with aromatic smell, and the misconception that waterpipe smoking is less toxic and addictive than cigarette smoking.

Keywords: adolescence, cigarette smoking, Iraq, waterpipe smoking, substance use

Citation: Mahmood N; Othman S; Al-Tawil N; Al-Hadithi T. Substance use among high school students in Erbil City, Iraq: prevalence and potential contributing factors. East Mediterr Health J. 2019;25(11):806-812. https://doi.org/10.26719/emhj.19.022

Received: 26/10/17; accepted: 03/04/18

Copyright $@$ C World Health Organization (WHO) 2019. Some rights reserved. This work is available under the CC BY-NC-SA 3.0 IGO license https:// creativecommons.org/licenses/by-nc-sa/3.o/igo.
\end{abstract}

\section{Introduction}

The problem of substance use involves all age levels but appears to be more dangerous and common in adolescence (1). Several factors are behind substance use, such as low socioeconomic status, unstructured time with peers, parental influences, psychosocial factors and community factors (2). Substance use and addiction are increasing worldwide especially among youth with diverse patterns in different countries (3). For example, according to the most recent report of the United Nations Office on Drugs and Crime (UNODC), the prevalence rate of substance use among people aged 15-64 years rose from $4.9 \%$ in 2006 to $5.3 \%$ in 2015 . This represents an increase of $0.4 \%$ since 2006 (4). In Iraq (including Kurdistan Region), according to the final report of the Iraq National Household Survey on Alcohol and Drug Use (INHSAD), the lifetime prevalence rates of tobacco use, alcohol consumption, nonmedical use of prescription drugs, and use of illicit drugs were $28.8 \%, 8.1 \%, 2.9 \%$, and $0.7 \%$, respectively (5). Another report, from the Iraqi Community Epidemiology Work Group, suggests that there has been increased use of alcohol and prescription and illicit drugs in Iraq since 2009, especially among adolescents (6). Studies conducted in countries bordering Iraq (Islamic Republic of
Iran and Turkey) have revealed that a high proportion of young people have reported substance use, including cigarettes, waterpipe smoking and alcohol consumption, at least once in their lifetime $(7,8)$.

To our knowledge, there is no nationwide survey on substance use among adolescents in the Kurdistan Region, Iraq, although a single study was conducted in Erbil City on the prevalence of health risk behaviour among male students of secondary schools (9). Therefore, the present study was performed to determine the prevalence of substance use and associated risk factors among high school students in Erbil City, in order to create a database to enable educational and health institutions to take the necessary measures to combat this phenomenon.

\section{Methods}

\section{Design and setting}

A cross-sectional descriptive study was carried out in Erbil City from 1 September 2016 to 31 March 2017. Erbil City is the capital of the Kurdistan Region, Iraq, situated $\sim 360 \mathrm{~km}$ north of Baghdad with a population of $\sim 1854$ 778 in 2018 (10). 


\section{Participants and sampling}

The target population of the study was high school students in Erbil City. An updated list of these schools was obtained from the Department of Statistics of the Directorate of Education of Erbil. We used a multistage cluster sampling technique for data collection. In the first stage, a sample of 30 schools was selected randomly from a list of 78 high schools using the Probability Proportional to Size sampling technique (11). A sample of 3000 students aged 14-19 years (100 students from each school) was selected based on the recommendations of UNODC (12). The main predictor variables for substance use (included in the questionnaire) were age, sex, paternal and maternal educational level, substance use by family member and friend, and accessibility of substances. In the second stage, a single class was selected randomly from grades 10,11 and 12 of each school. Then from each selected class, a random sample of students was selected as follows: 30 students from grade 10, 35 from grade 11, and 35 from grade 12 , as the total number of students in each class was $>40$.

\section{Measures}

A validated self-administered questionnaire developed by UNODC was used as a survey instrument for collecting data (12). Taking into account the circumstances of substance use and cultural relevancy in Kurdistan Region, the wording and format of the questionnaire were modified and translated into the local Kurdish language to ensure that it could be easily understood by the students. The questionnaire comprised 3 sections. The first section was related to sociodemographic variables such as age, gender, educational level of parents, and monthly family income, which was categorized into 3 groups: more than enough, enough, and less than enough. The second section identified some of the associated risk factors such as family substance use, friends' use of substances, and accessibility of substances. The third section of the questionnaire assessed the pattern of substance use. Prior to the start of the study, the questionnaire was piloted on 30 students from grades 10, 11 and 12, who were excluded from the final sample. Based on the pilot study findings, necessary modifications were made to clarify some of the items. The self-administered questionnaire was completed inside the classroom by the students. This process lasted for 15-20 minutes. School social workers "rabers" from the 30 schools participated in data collection. They were trained in the correct method of data collection.

\section{Ethical considerations}

Written informed consent was obtained from the parent of each student before being enrolled in the study. The project was approved by the Research Ethics Committee of the College of Medicine of Hawler Medical University, Erbil City, Iraq. Official permission was obtained from the Directorate of Education of Erbil as well as from the administration of each high school to carry out the study. All students were assured that their participation in the study was voluntary; they were in- formed about the purpose of the study; and their anonymity and confidentiality were assured.

\section{Statistical analysis}

SPSS version 21 was used for data processing and statistical analysis. Data were analysed through the use of a simple descriptive approach and inferential approach $\left(\chi^{2}\right.$ test) for the association between sociodemographic variables and substance use. Variables found by $\chi^{2}$ test to be significantly associated with substance use were entered into a binary logistic regression model in which the dependent variable was lifetime substance use. $P \leq$ 0.05 was considered to be statistically significant.

\section{Results}

Out of the 3000 questionnaires, 257 were discarded as they lacked some of the data. Among the participants, $1545(56.3 \%)$ were males and $1198(43.7 \%)$ were females. The mean (standard deviation) age of the sample was 16.70 (1.249) years, with a range of $14-19$ years.

Prevalence of cigarette smoking among the students over their lifetime, last 12 months and last 30 days was $27.6 \%, 16.3 \%$ and $13.0 \%$, respectively (Table 1 ). The lifetime prevalence of waterpipe smoking, alcohol consumption and use of unprescribed tranquilizers was $23.8 \%, 3.7 \%$ and $1.4 \%$, respectively. Due to the small numbers of students

Table 1 Prevalence of substance abuse among high school students in Erbil city $(n=2743)$

\begin{tabular}{|c|c|c|c|}
\hline Types of substance & $\begin{array}{c}\text { Lifetime } \\
\text { No. (\%) }\end{array}$ & $\begin{array}{c}12 \text { months } \\
\text { No. (\%) }\end{array}$ & $\begin{array}{c}30 \text { days } \\
\text { No. (\%) }\end{array}$ \\
\hline Cigarette & $758(27.6)$ & $446(16.3)$ & $356(13.0)$ \\
\hline Waterpipe & $652(23.8)$ & $419(15 \cdot 3)$ & $311(11.3)$ \\
\hline Alcohol & $101(3.7)$ & $62(2.3)$ & $61(2.2)$ \\
\hline $\begin{array}{l}\text { Un-prescribed } \\
\text { tranquilizers or sedatives }\end{array}$ & $39(1.4)$ & $24(0.9)$ & $24(0.9)$ \\
\hline Amphetamines & $30(1.1)$ & $16(0.6)$ & $16(0.6)$ \\
\hline Methamphetamine & $26(0.9)$ & $16(0.6)$ & $11(0.4)$ \\
\hline Marijuana (Hashish) & $20(0.7)$ & $9(0.3)$ & $7(0.3)$ \\
\hline Unprescribed opioids & $13(0.5)$ & $8(0.3)$ & $7(0.2)$ \\
\hline Solvents or inhalants & $12(0.4)$ & $10(0.4)$ & $7(0.2)$ \\
\hline Ecstasy & $11(0.4)$ & $7(0.2)$ & $3(0.1)$ \\
\hline Heroin & $7(0.3)$ & $4(0.1)$ & $4(0.1)$ \\
\hline Cocaine & $5(0.2)$ & $5(0.2)$ & $4(0.1)$ \\
\hline Crack & $4(0.1)$ & $4(0.1)$ & $3(0.1)$ \\
\hline
\end{tabular}




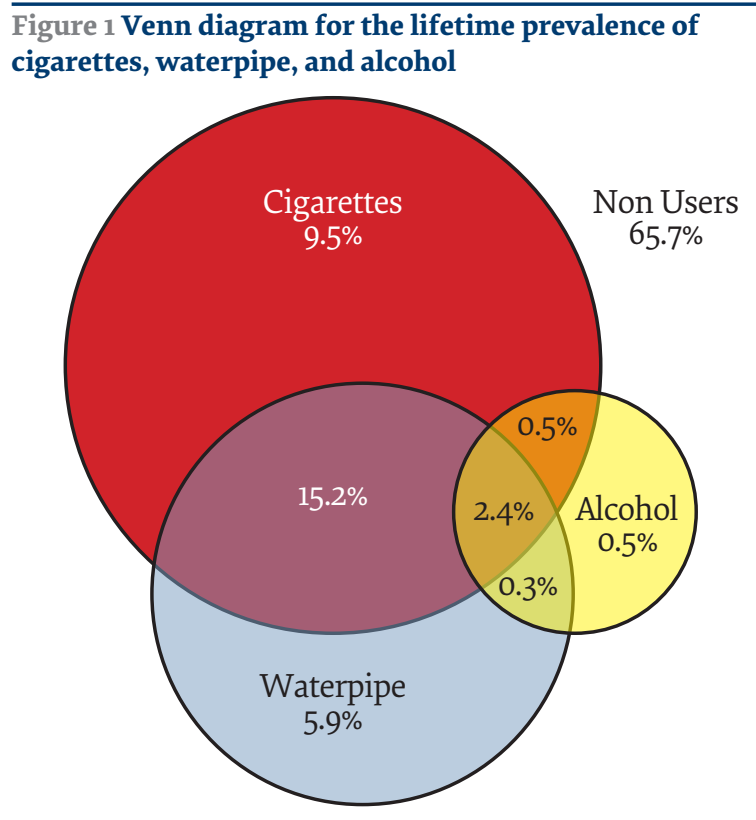

who have ever used marijuana (hashish) and other illicit drugs, their statistics were only been described and no further analysis was done.

Figure 1 shows that the lifetime prevalence of use of any of the mentioned substances was $34.3 \%$, either alone or in combination.

Prior to regression analysis, the association between substance use (cigarettes, waterpipe smoking and alcohol) and the mentioned predictor variables was studied, and the significance was tested using the $\chi^{2}$ test of association.
A significant association was detected between substance use and age and sex $(P<0.001)$, and between monthly family income and cigarette smoking $(P=0.035)$, waterpipe smoking $(P=0.015)$ and alcohol consumption $(P<0.001)$. Significant associations $(P<0.001)$ were detected between substance use and substance use by family members or friends, and substance accessibility.

Binary logistic regression revealed that being male was significantly associated with cigarette smoking, waterpipe smoking and alcohol consumption (Table 2). Age 17-19 years was significantly associated with cigarette smoking and waterpipe smoking. Low family income increased the likelihood of alcohol consumption. A substance user in the family increased the likelihood of cigarette smoking, waterpipe smoking and alcohol consumption. Substance use by a friend was the strongest predictor of cigarette smoking, waterpipe smoking and alcohol consumption. Easy access to substances was a risk factor for using such substances.

\section{Discussion}

The principal finding of this study is that cigarette smoking and waterpipe smoking are the major forms of substance use by students in Erbil City. Approximately, one third of the students have smoked cigarettes during their lifetime and almost one quarter of them have used a waterpipe. This agrees with the findings of a study conducted in neighbouring Islamic Republic of Iran, which showed that the most widely used substances among students were cigarettes and waterpipe (7). The high

\begin{tabular}{|c|c|c|c|c|c|c|c|c|c|}
\hline \multirow[t]{2}{*}{ Covariates } & \multicolumn{3}{|c|}{ Cigarette smoking } & \multicolumn{3}{|c|}{ Waterpipe } & \multicolumn{3}{|c|}{ Alcohol drinking } \\
\hline & OR & $95 \% \mathrm{CI}$ & $\mathbf{P}$ & OR & $95 \% \mathrm{CI}$ & $\mathbf{P}$ & OR & $95 \% \mathrm{CI}$ & $\boldsymbol{P}$ \\
\hline Male gender & 1.558 & $1.213-2.000$ & 0.001 & 1.364 & $1.041-1.789$ & 0.025 & 2.418 & $1.308-4.473$ & 0.005 \\
\hline \multicolumn{10}{|l|}{ Age (years) } \\
\hline \multicolumn{10}{|l|}{ 14-16 (Reference) } \\
\hline $17-19$ & 1.221 & $1.002-1.488$ & 0.048 & 1.262 & $1.023-1.557$ & 0.030 & 1.291 & $0.767-2.173$ & 0.337 \\
\hline \multicolumn{10}{|l|}{ Family income } \\
\hline \multicolumn{10}{|c|}{ More than enough (Reference) } \\
\hline Enough & 0.872 & $0.691-1.100$ & 0.249 & 1.072 & $0.835^{-1.376}$ & 0.584 & 0.518 & $0.310-0.865$ & 0.012 \\
\hline Less than enough & 0.920 & $0.548-1.543$ & 0.751 & 1.172 & $0.686-2.004$ & 0.561 & 2.345 & $1.030-5.337$ & 0.042 \\
\hline Family use of substances & 1.349 & $1.108-1.641$ & 0.003 & 1.684 & $1.370-2.070$ & $<0.001$ & 5.189 & $2.957-9.108$ & $<0.001$ \\
\hline Friends' use of substances ${ }^{a}$ & 3.942 & $3.103-5.009$ & $<0.001$ & 4.619 & $3.547-6.015$ & $<0.001$ & 8.867 & $5 \cdot 399-14.561$ & $<0.001$ \\
\hline \multicolumn{10}{|l|}{ Accessibility of substances $^{b}$} \\
\hline \multicolumn{10}{|c|}{ Impossible and very difficult (Reference) } \\
\hline Fairly difficult & 6.691 & $3.361-13.317$ & $<0.001$ & 4.495 & $2.503-8.071$ & $<0.001$ & 2.725 & $0.906-8.195$ & 0.074 \\
\hline Fairly easy & 4.365 & $2.997-6.356$ & $<0.001$ & 4.543 & $3.170-6.511$ & $<0.001$ & 3.504 & $1.201-10.223$ & 0.022 \\
\hline Very easy & 4.321 & $3.439-5.430$ & $<0.001$ & 4.352 & $3.402-5.566$ & $<0.001$ & 2.628 & $1.221-5.656$ & 0.014 \\
\hline Don't know & 1.742 & $1.270-2.387$ & 0.001 & 1.515 & $1.081-2.124$ & 0.016 & 1.096 & $0.534-2.250$ & 0.803 \\
\hline
\end{tabular}

aDefined as a person in close contact with the student, whether in school or outside, which used at least one of the substances listed in the questionnaire.

${ }^{b}$ Defined as the local ease of distribution, access, and affordability. $\mathrm{OR}=$ odds ratio; $\mathrm{CI}=$ confidence interval. 
prevalence of waterpipe smoking in this study confirms the international and national literature that waterpipe smoking is a social phenomenon that has increased in popularity worldwide especially among adolescents (13, 14). Possible explanations for this finding might be the use of flavoured tobacco associated with aromatic smell, and the misconception that waterpipe smoking is less toxic and addictive than cigarette smoking (15).

Although international trends indicate that alcohol is the first and most widely used substance among students globally (16), the prevalence of alcohol consumption in the current study was relatively low. This was mostly related to religious beliefs and prohibition of alcohol in Islam, knowing that most of the population of Erbil is Muslim.

Numerous studies have shown that males are more likely to use substances than females, which agrees with our findings $(1,17)$. Multiple factors such as social stigma, cultural values, and availability and accessibility of substances to male students could be behind the low substance use among female students (18).

As reported previously (19), increasing age of the students in this study was significantly associated with substance use. The reason behind this could be the easy accessibility of substances with increasing age. The addictive nature of substance use is another contributing factor; students who fail to quit the habit continue using substances in late adolescence.

Some studies have indicated that there is an association between family socioeconomic status and adolescent substance use (20). However, our study did not clearly confirm that; except for our finding that family income was inversely associated with alcohol consumption. This coincides with another study that reported that poverty was a predisposing factor for alcohol consumption (21). A possible explanation for this association is the psychosocial consequences linked to poverty; students may drink alcohol to minimize multiple stressors such as poorer housing, lack of affordable day care, and social discrimination. Moreover, alcohol is not expensive in Iraq.

Family members' behaviour in our study was another important risk factor for substance use, and lifetime substance use was related to familial use. This agrees with that reported by Whitesell et al. in the United States of America (22). Having a father, mother or siblings who are substance users increased the odds of cigarette smoking by 1.5 times, 1.36 times for waterpipe smoking, and considerably more than 5 times for alcohol consumption, compared with those who did not have a substance user in the family. Family members, especially parents, who use substances in front of their children act as a role model and this creates indirectly the impression that substance use is acceptable behaviour among adults (23). This, in turn, poses a real threat to children by imitating their parents' behaviour. As a result, substance use can spread among family members. Moreover, parents may also consume alcohol because of depression, bipolar disorder, psychosis or personality disorder. These disorders have a genetic predisposition that can be expressed in offspring (24).
The present study confirmed that peer influence is the strongest risk factor associated with substance use in schools. This coincides with the report by Rukundo et al. in Uganda (25). In accordance with the study by Zarrouq et al. in Morocco (26), we found that smoking among friends increased the likelihood of cigarette and waterpipe smoking among adolescents. Similarly, having a friend who consumed alcohol was the strongest and most reported factor that influenced alcohol consumption in our study, which agrees with the findings of Patrick and Schulenberg in the United States (27). In contrast, having a friend who does not engage in risky behaviour, will contribute to a lower risk of being a substance user. This might be explained by peer pressure and social learning theory that assumes that children can learn bad behaviour from watching their peers. As peers are an important element of social support, their pressure can be an enforcer for a good or bad behaviour (28).

The results of this study demonstrated another factor associated with substance use, which is the accessibility of substances. This coincides with a study done in the United States (29). The present study confirmed the expected positive relationship between accessibility of cigarettes, waterpipes and alcohol and their use. It is known that availability and accessibility of substances is one of the factors that has contributed to their increasing use during recent decades (30). In Erbil, cigarettes and waterpipes are widely available in markets, cafes, clubs, restaurants and parks. Hence, they are easily obtained. Waterpipe smoking is a new phenomenon that has become fashionable in Kurdish society (14). This has prompted the Ministry of Health of the Kurdistan Region to halt licensing the use of waterpipes in public places and not to renew old licenses until a final decision is made about this issue (31). Probably, several factors are behind the increase in waterpipe use, such as lack of responsibility of vendors and consumers, increasing wealth in recent years, social influences, increased availability, and easy access to waterpipes $(14,32)$.

This study had some limitations, including the crosssectional design of the study, which meant that we could not conclude whether the risk factors preceded or followed substance use. Another limitation was the selfreporting and accuracy with which students completed the questionnaires. Since this study was conducted in the school environment, its finding cannot be generalized to include users elsewhere.

\section{Conclusion}

Cigarettes, waterpipe and alcohol were the most commonly used substances. Having a family member using such substances, peer influence, and availability of substances were the most observable risk factors. Developing and implementing a health education programme in high schools is necessary to raise awareness of the consequences of this phenomenon. This, in turn, could prevent substance use among this segment of the population.

Funding: None.

Competing interests: None declared. 


\section{Utilisation de substances psychoactives parmi les élèves du cycle secondaire à Erbil (Iraq) : prévalence et facteurs de contribution potentiels Résumé}

Contexte: L'utilisation de substances psychoactives parmi les adolescents, en particulier le tabagisme et la consommation d'alcool, est devenue une préoccupation de santé publique dans la Région du Kurdistan (Iraq), au cours des 10 dernières années.

Objectif : Déterminer la prévalence de l'utilisation de substances psychoactives et de certains facteurs associés parmi les élèves du cycle secondaire à Erbil, Région du Kurdistan (Iraq).

Méthodes: Une étude transversale a été réalisée par sondage en grappes à plusieurs degrés afin de collecter un échantillon de 3000 élèves. Une version modifiée de l'enquête sur la consommation de drogue au sein des établissements scolaires de l'Office des Nations Unies contre la Drogue et le Crime a été utilisée aux fins de la collecte des données. Des modèles de régression logistique binaire ont été employés afin d'identifier les facteurs de risque liés à l'utilisation de substances psychoactives.

Résultats : Les taux de prévalence sur la durée d'une vie du tabagisme par cigarettes et par narguilé, ainsi que de la consommation d'alcool étaient de 27,6\%, 23,6\% et de 3,7\% respectivement. Le tabagisme par cigarettes était associé de manière significative à l'appartenance au sexe masculin, à un âge compris entre 17 et 19 ans, au fait d'avoir un fumeur au sein de la famille et à un accès facile aux cigarettes. Les facteurs associés de manière significative au tabagisme par narguilé étaient l'appartenance au sexe masculin, un âge compris entre 17 et 19 ans, le fait d'avoir un fumeur de narguilé dans la famille ou parmi les amis, et un accès aisé. L'appartenance au sexe masculin, le fait d'avoir un membre de la famille ou un ami alcoolique, la facilité d'accès à l'alcool et le faible revenu familial étaient des facteurs prédictifs significatifs de la consommation d'alcool.

Conclusion : La prévalence du tabagisme par cigarettes et par narguilé était élevée dans l'échantillon soumis à l'étude. Les éléments qui peuvent expliquer cette constatation pourraient être liés à l'utilisation de tabac aromatisé et aux fumées qui s'en dégagent ainsi qu'à l'idée érronée selon laquelle le tabagisme par narguilé est moins toxique et crée moins de dépendance que le tabagisme par cigarettes.

$$
\text { تنعاطي المخدرات في أوساط طلاب المدارس الثانوية في مدينة أربيل بإقليم كردستان: معدل الانتشار والعوامل }
$$

الخلفية: أصبح تعاطي المخدرات في أوساط المراهقين، لا سيا التدخين وتعاطي المسكرات، أحد شو اغل الصحة العامة في إقليم كردستان بالعراق في السنوات العشر الماضضية.

الأهداف: هدفت هذه الدراسة إلى تحديد معدل انتشار تعاطي المخدرات وبعض العوامل ذات الصلة في أوساط طلاب المدارس الثانوية في مدينة أربيل، إقليم كردستان، العراق هدفته الفراف

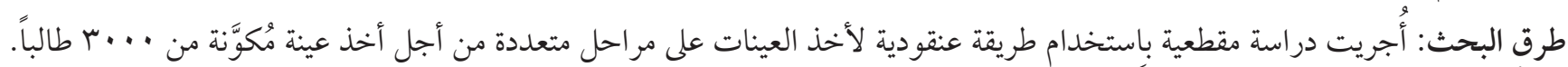

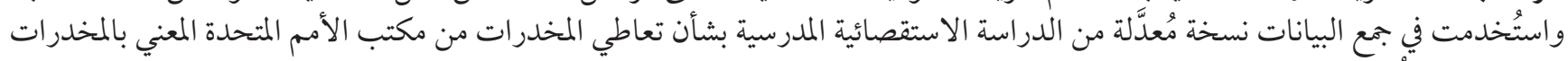

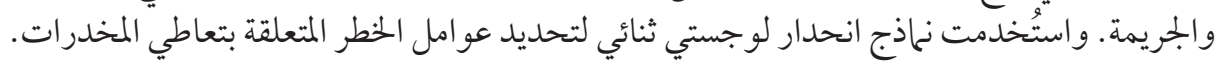

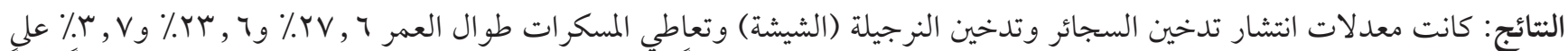

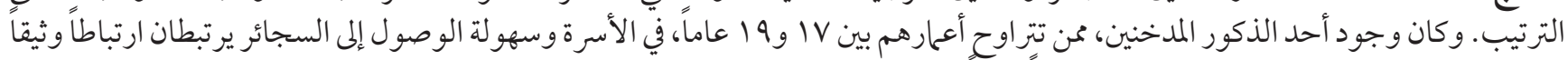

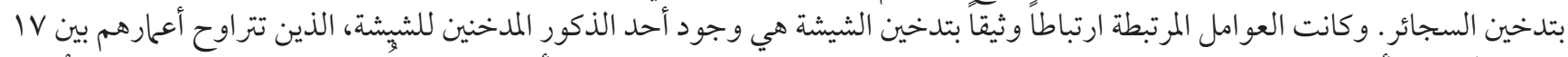

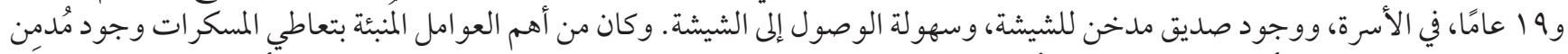

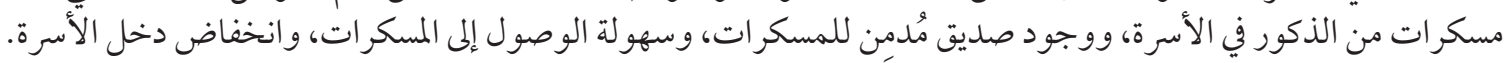

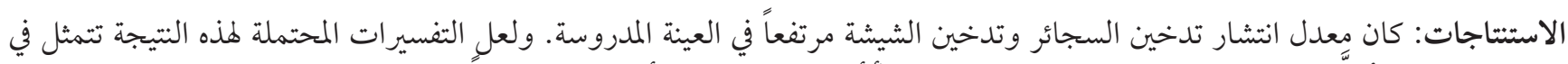

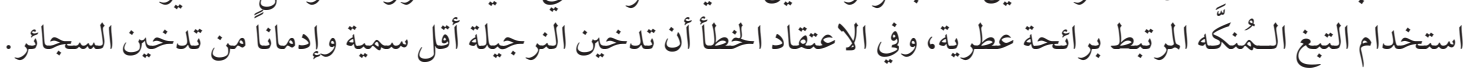




\section{References}

1. Tshitangano TG, Tosin OH. Substance use amongst secondary school students in a rural setting in South Africa: prevalence and possible contributing factors. Afr J Prim Health Care Fam Med. 2016 Apr 8;8(2):e1-6. http://dx.doi.org/10.4102/phcfm.v8i2.934 PMID:27380837

2. Alhyas L, Ozaibi NA, Elarabi H, El-Kashef A, Wanigaratne S, Almarzouqi A, et al. Adolescents' perception of substance use and factors influencing its use: a qualitative study in Abu Dhabi. J R Soc Med. 2015 Mar 2;6(2):1-12. http://dx.doi. org/10.1177/2054270414567167 PMID:25780594

3. Das JK, Salam RA, Arshad A, Finkelstein Y, Bhutta ZA. Interventions for adolescent substance abuse: an overview of systematic reviews. J Adolesc Health. 2016 Oct;59(4):S61-75. http://dx.doi.org/10.1016/j.jadohealth.2016.06.021. PMID:27664597

4. Global overview of drug demand and supply: Latest trends, cross-cutting issues. World Drug Report 2017. Vienna: United Nations Office on Drugs and Crime; 2017 (https://www.unodc.org/wdr2017/field/Booklet_2_HEALTH.pdf, accessed 19 April 2019).

5. Al-Hemiery N, Dabbagh R, Hashim MT, Al-Hasnawi S, Abutiheen A, Abdulghani EA, et al. Self-reported substance use in Iraq: findings from the Iraqi National Household Survey of Alcohol and Drug Use, 2014. Addiction. 2017 Aug;112(8):1470-9. http://dx. doi.org/10.1111/add.13800. PMID:28238214

6. Al-Hemiary NJ, Al-Diwan JK, Hasson AL, Rawson RA. Drug and alcohol use in Iraq: findings of the inaugural Iraqi Community Epidemiological Workgroup. Subst Use Misuse. 2014 Nov;49(13):1759-63. http://dx.doi.org/10.3109/10826084.2014.913633. PMID:24827867

7. Akhavan S, Arti S, Qaraat L, Geramian N, Farajzadegan Z, Heidari K, et al. A review study of substance abuse status in high school students, Isfahan, Iran. Int J Prev Med. 2014 Dec; 5(Suppl 2):S77-82. http://dx.doi.org/10.4103/2008-7802.157661. PMID:26157571

8. Evren C, Ogel K, Demirci A, Evren B, Yavuz B, Bozkurt M. Prevalence of lifetime tobacco, alcohol and drug use among 10th grade students in Istanbul. Klinik Psikofarmakoloji Bülteni. 2014;24(3):201-10. http://dx.doi.org/10.5455/bcp.20140131023259

9. Baker JA, Al-Doski N. Health risk behaviors among male students in secondary schools in Erbil city. Zanco J Med Sci. 2016;20(1):1199-205. http://dx.doi.org/10.15218/zjms.2016.0009

10. Erbil Governorates, Regions and Major Cities - population statistics in maps and charts [website] (https://www.citypopulation. de/Iraq-Cities.html, accessed 22 April 2019).

11. Steps in applying Probability Proportional to Size (PPS) and calculating Basic Probability Weight (http://www.who.int/tb/advisory_bodies/impact_measurement_taskforce/meetings/prevalence_survey/psws_probability_prop_size_bierrenbach.pdf://, accessed 19 April 2019).

12. Conducting school surveys on drug abuse. Global Assessment Programme on Drug Abuse. Toolkit module 3. Vienna: United Nations for Drugs and Crime; 2003 (https://www.unodc.org/documents/GAP/GAP\%20Toolkit\%20Module\%203\%20ENGLISH.pdf, accessed 19 April 2019).

13. Essau, CA. Adolescent addiction: epidemiology, assessment and treatment. Academic Press; 2008.

14. Jaff D, Kumar A. The waterpipe epidemic: emerging public health threat in the Kurdish Region of Iraq. J Health Syst. 2016 JanJun;2(1):16-18.

15. WHO Study Group on Tobacco Product Regulation (TobReg). Waterpipe tobacco smoking: health effects, research needs and recommended actions for regulators - 2nd ed. Geneva: World Health Organization; 2015 (https://apps.who.int/iris/bitstream/10665/161991/1/ 9789241508469_eng.pdf, accessed 19 April 2019).

16. Global status report on alcohol and health. Geneva: World Health Organization; 2014 (https://www.who.int/iris/bitstre am/10665/112736/1/9789240692763_eng.pdf, accessed 30 April 2019).

17. United Nations Educational, Scientific and Cultural Organization (UNESCO), United Nations Office on Drugs and Crime, WHO. Education sector responses to the use of alcohol, tobacco and drugs. Paris: United Nations Educational, Scientific and Cultural Organization; Vienna: United Nations Office on Drugs and Crime; Geneva: World Health Organization; 2017 (Good policy and practice in health education: booklet 10. 2017, https://www.unodc.org/documents/drug-prevention-and-treatment/UNODC_UNESCO_WHO_GoodPolicyAndPracticeInHealthEducation.pdf, accessed 19 April 2019).

18. Heydari ST, Izedi S, Sarikhani Y, Kalani N, Akbary A, Miri A, et al. The prevalence of substance use and associated risk factors among university students in the city of Jahrom, Southern Iran. Int J High Risk Behav Addict. 2015 Jun 20;4(2):e22381. http://dx.doi.org/10.5812/ijhrba. PMID:26097836

19. Mohammadpoorasl A, Nedjat S, Fakhari A, Yazdani K, Foroushani AR, Fotouhi A. Substance abuse in high school students in association with socio-demographic variables in northwest of iran. Iran J Public Health. 2012 Dec 1;41(12):40-46 PMID:23641389

20. Lemstra M, Bennett NR, Neudorf C, Kunst A, Nannapaneni U,Warren LM, et al. A meta-analysis of marijuana and alcohol use by socio-economic status in adolescents aged 10-15 years. Can J Public Health. 2008 May-Jun;99(3):172-7. PMID:18615935

21. Jones L, Sumnall H. Understanding the relationship between poverty and alcohol misuse. Liverpool: Centre for Public Health, Liverpool John Moores University; 2016 (http://www.cph.org.uk/wp-content/uploads/2016/06/Understanding-the-relationship-between-poverty-and-alcohol-abuse.pdf, accessed 19 April 2019).

22. Whitesell M, Bachand A, Peel J, Brown M. Familial, social, and individual factors contributing to risk for adolescent substance use. J Addict. 2013;2013:579310. http://dx.doi.org/10.1155/2013/579310. PMID:24826363 
23. Lim KH, Lim HL, Teh CH, Kee CC, Khoo YY, Ganapathy SS, et al. Smoking among school-going adolescents in selected secondary schools in Peninsular Malaysia-findings from the Malaysian Adolescent Health Risk Behaviour (MyaHRB) study. Tob Induc Dis. 2017 Jan 31;15(1):9. http://dx.doi.org/10.1186/s12971-016-0108-5 PMID:28163668

24. Ruiz P, Strain EC. The substance abuse handbook. Philadelphia: Lippincott Williams \& Wilkins; 2014.

25. Rukundo A, Kibanja G, Steffens K. Factors influencing psychoactive substance use among adolescents in public secondary schools in Uganda. Int J Alcohol Drug Res. 2017;6(1):69-76. http://dx.doi.org/10.7895/ijadr.v6i1.237

26. Zarrouq B, Bendaou B, Asri AE, Achour S, Rammouz I, Aalouane R, et al. Psychoactive substances use and associated factors among middle and high school students in the North Center of Morocco: a cross-sectional questionnaire survey. BMC Public Health. 2016 Jun 4;16:468. http://dx.doi.org/10.1186/s12889-016-3143-5 PMID:27262322

27. Patrick ME, Schulenberg JE. Alcohol use and heavy episodic drinking prevalence and predictors among national samples of American eighth and tenth-grade students. J Stud Alcohol Drugs. 2010 Jan:71(1):41-5. PMID:20105412

28. Peer pressure and substance abuse [website]. Drug and Alcohol Rehab in Thailand (http://alcoholrehab.com/drug-addiction/peerpressure-and-substance-abuse/, accessed 19 April 2019).

29. Broman CL. The availability of substances in adolescence: influences in emerging adulthood. J Child Adolesc Subst Abuse. 2016;25(5):487-95. PMID:29200806

30. Somani S, Meghani S. Substanceuse among youth: a harsh reality. Emerg Med. 2016;6:330. http://dx.doi.org/10.4172/2165 7548.1000330.

31. Health Ministry halts licensing for shisha in public in Kurdistan [website]. Rudaw; 2017 (http://www.rudaw.net/english/kurdis$\tan / 260320171$, accessed 19 April 2019).

32. Shisha: the new phenomenon in our society [website]. WAARmedia; 2017 (http://waarmedia.com/english/21199-2/, accessed 19 April 2019). 